\title{
MORTAR-BASED SYSTEMS FOR EXTERNALLY BONDED STRENGTHENING OF MASONRY
}

\author{
Gianmarco de Felice ${ }^{1, *}$, Stefano De Santis ${ }^{1}$, Leire Garmendia ${ }^{2}$, Bahman \\ Ghiassi $^{3}$, Pello Larrinaga ${ }^{2}$, Paulo B. Lourenço ${ }^{3}$, Daniel V. Oliveira ${ }^{3}$, Fabrizio \\ Paolacci $^{1}$, Catherine G. Papanicolaou ${ }^{4}$ \\ ${ }^{1}$ Department of Engineering, Roma Tre University, Rome, Italy \\ ${ }^{2}$ Tecnalia Research \& Innovation, Bilbao, Spain \\ ${ }^{3}$ Department of Civil Engineering, ISISE, University of Minho, Guimaraes, Portugal \\ ${ }^{4}$ Department of Civil Engineering, University of Patras, Patras, Greece \\ * Corresponding author: \\ E-mail: gianmarco.defelice@uniroma3.it \\ Telephone: +39.06 .5733 .6268$ \\ Fax: +39.06 .5733 .6265$
}

\begin{abstract}
Mortar-based composite materials appear particularly promising for use as externally bonded reinforcement (EBR) systems for masonry structures. Nevertheless, their mechanical performance, which may significantly differ from that of Fibre Reinforced Polymers, is still far from being fully investigated. Furthermore, standardized and reliable testing procedures have not been defined yet. The present paper provides an insight on experimental-related issues arising from campaigns on mortar-based EBRs carried out by laboratories in Italy, Portugal and Spain. The performance of three reinforcement systems made out of steel, carbon and basalt textiles embedded in inorganic matrices has been investigated by means of uniaxial tensile coupon testing and bond tests on brick and stone substrates. The experimental results contribute to the existing knowledge regarding the structural behaviour of mortar-based EBRs against tension and shear bond stress, and to the development of reliable test procedures aiming at their homogenization/standardization.
\end{abstract}

Keywords: Masonry, Mortar-based composites, Tensile tests, Bond tests.

\section{INTRODUCTION}

An increasing attention has been given in the recent years to the development of innovative technologies based on the use of composite materials for strengthening masonry structures by applying externally bonded reinforcement systems. Applications of Fibre Reinforced Polymers (FRP) to vaults, columns and walls have demonstrated their effectiveness in increasing the load-carrying capacity and in upgrading the seismic strength (Triantafillou and Fardis, 1997; 
Valluzzi et al., 2001; Corradi et al., 2002; Ascione et al., 2005; Grande et al., 2011; Oliveira et al., 2011; Valluzzi et al., 2014). During the past decade, in an effort to alleviate certain drawbacks associated to the organic character of polymer-based composites, fibre-reinforced inorganic matrix composites have been developed. This broad category includes Steel Reinforced Grouts (SRG, unidirectional steel cords embedded in a cement or lime grout) and FabricReinforced Cementitious Matrix (FRCM) composites (a sequence of one or more layers of cement-based matrix reinforced with dry fibres in the form of open single or multiple meshes, Babaeidarabad et al., 2013)

Inorganic matrices may exhibit lower bond strength with respect to FRPs, due to the possible occurrence of failure modes within the reinforcement rather than within the substrate. However, they are advantageous in terms of overlay-tosubstrate compatibility, transpirability, reversibility, fire resistance, cost, and applicability (Papanicolaou et al., 2007; 2008; Cancelli et al., 2007; Carbone and de Felice 2008; Borri et al., 2011; Garmendia et al., 2011; Malena and de Felice, 2014). Moreover, they seem to be particularly appropriate for application to masonry structures, since the higher bond strength of polymeric matrices cannot be fully exploited because of the low intrinsic mechanical characteristics of the substrate (Oliveira et al., 2011; Garmendia et al., 2012; Grande et al., 2013; Ceroni et al., 2014). Nevertheless, a deeper knowledge needs to be gained for designing mortar-based strengthening systems that are suitable for application to masonry substrates, as well as for identifying their mechanical properties (e.g., under direct tension or shear bond stress) through standardized testing methodologies.

Systemized research on similar systems, such as Textile Reinforced Concrete (TRC), has been recently conducted (Brameshuber, 2006). Despite the fact that the main target of TRC was originally integration in new civil applications rather than strengthening of existing ones, strong analogies exist between mortar-based reinforcement systems and TRC on numerous key issues, including testing methods (Contamine et al., 2011; Hartig et al., 2012, Hegger et al., 2006; HäußlerCombe and Hartig, 2007; Colombo et al., 2013), durability and mechanical behaviour. TRC matrices usually consist of high performance finely grained cement concrete, while lime-based mortars might be preferred when strengthening a masonry structure to fulfil moisture compatibility and reversibility requirements. As for the reinforcement textiles, beyond those typically used in TRC (glass, carbon or aramid fibre bundles), steel cords (Borri et al., 2011), basalt (Balsamo et al., 2011), and natural fibres (Pacheco-Torgal and Jalali, 2011) may be potentially selected for the strengthening of masonry, provided that fabric layouts are designed to ensure adequate interlocking within a weaker matrix.

In the perspective of using mortar-based composites as strengthening system, more research is needed to explore the bond performance, for which only few contributions have been provided to date,(see for instance: Ortlepp et al., 2006; Faella et al., 2008; Carbone and de Felice, 2009; D’Ambrisi et al., 2013, D'Antino et al., , 2014; Carozzi et al., 2014).

The present work describes the results of an experimental campaign devoted to the investigation of the mechanical performance of reinforcement systems comprising fibrous textiles embedded in inorganic matrices. The research is currently on-going within the RILEM TC CSM (Composites for sustainable strengthening of masonry). Three research laboratories, affiliated with the University Roma Tre (Rome, Italy, UNIRM3), the University of Minho 
(Guimarães, Portugal, UMINHO), and Tecnalia Research \& Innovation (Bilbao, Spain, TECNALIA) were involved. The experimental programme comprised Steel Reinforced Grouts (SRG), Carbon Textile Reinforced Mortars (CTRM) and Basalt Textile Reinforced Mortars (BTRM). Both cement-based and lime-based mortars have been used as matrices. The three composite systems were characterised through direct unidirectional tensile tests. Then, the composite-tosubstrate bond performance was investigated using different test setups (single or double lap scheme) and considering various anchorage lengths, substrates (brick and stone), and surface preparation techniques.

\section{MATERIALS}

The properties of the materials used to manufacture the specimens are listed in Tables 1 and 2. The former includes the type, the compressive strength $\left(f_{b}, f_{m}\right)$ and the Young's modulus $\left(\mathrm{E}_{\mathrm{b}}, \mathrm{E}_{\mathrm{m}}\right)$ of the substrates and mortar matrices. The tensile strength of the mortar matrices $\left(\mathrm{f}_{\mathrm{mt}}\right)$, derived through three point bending tests, is also reported. EN 1926 (2006), EN 772-1 (2002), and EN 1015-11 (2007) standards were followed for the tests on natural stones, bricks, and mortars, respectively.

Table 1 Mechanical properties of substrates and matrices

\begin{tabular}{|c|c|c|c|c|c|c|c|c|c|}
\hline \multicolumn{3}{|c|}{ Institution } & \multicolumn{3}{|c|}{ Substrate } & \multicolumn{4}{c|}{ Matrix } \\
\hline Name & Acronym & Country & Type & $\begin{array}{c}\mathrm{f}_{\mathrm{b}} \\
\mathrm{N} / \mathrm{mm}^{2}\end{array}$ & $\begin{array}{c}\mathrm{E}_{\mathrm{b}} \\
\mathrm{N} / \mathrm{mm}^{2}\end{array}$ & Type & $\begin{array}{c}\mathrm{f}_{\mathrm{m}} \\
\mathrm{N} / \mathrm{mm}^{2}\end{array}$ & $\begin{array}{c}\mathrm{E}_{\mathrm{m}} \\
\mathrm{N} / \mathrm{mm}^{2}\end{array}$ & $\begin{array}{c}\mathrm{f}_{\mathrm{mt}} \\
\mathrm{N} / \mathrm{mm}^{2}\end{array}$ \\
\hline $\begin{array}{c}\text { Roma Tre } \\
\text { University }\end{array}$ & UNIRM3 & Italy & Brick & 55.2 & 16000 & $\begin{array}{c}\text { Fibre-reinforced } \\
\text { cement-based } \\
\text { mortar }\end{array}$ & 38.0 & 15000 & 7.5 \\
\hline $\begin{array}{c}\text { University } \\
\text { of Minho }\end{array}$ & UMINHO & Portugal & Brick & 14.2 & 9500 & $\begin{array}{c}\text { Lime-based } \\
\text { mortar }\end{array}$ & 13.0 & 14000 & 3.2 \\
\hline $\begin{array}{c}\text { Tecnalia } \\
\text { R\&I }\end{array}$ & TECNALIA & Spain & Stone & 21.0 & 5900 & $\begin{array}{c}\text { Cement-based } \\
\text { polymer- } \\
\text { modified mortar }\end{array}$ & 22.6 & 15700 & 2.5 \\
\hline
\end{tabular}

Table 2 contains the type and the properties of the filament/wire (tensile strength, $\mathrm{f}_{\mathrm{fil}}$, Young's modulus, $\mathrm{E}_{\mathrm{fil}}$, and ultimate strain, $\left.\varepsilon_{\mathrm{u}, \mathrm{fil}}\right)$, the properties of the textile (tensile resistance, $\mathrm{f}_{\mathrm{t}}$, Young's modulus, $\mathrm{E}_{\mathrm{f}}$, ultimate strain, $\varepsilon_{\mathrm{u}}$, and weight, $\mathrm{W})$ and its equivalent thickness (t).

Table 2 Textile tensile properties

\begin{tabular}{|c|c|c|c|c|c|c|c|c|c|}
\hline \multirow[b]{2}{*}{ Type } & \multirow[b]{2}{*}{ Institution } & \multicolumn{3}{|c|}{ Filament $^{(1)}$} & \multicolumn{5}{|c|}{ Textile } \\
\hline & & $\begin{array}{c}\mathrm{f}_{\text {fil }} \\
\mathrm{N} / \mathrm{mm}^{2}\end{array}$ & $\begin{array}{c}\mathrm{E}_{\mathrm{fil}} \\
\mathrm{N} / \mathrm{mm}^{2}\end{array}$ & $\begin{array}{c}\varepsilon_{\mathrm{u}, \mathrm{fil}} \\
\%\end{array}$ & $\begin{array}{c}\mathrm{f}_{\mathrm{t}}^{(2)} \\
\mathrm{N} / \mathrm{mm}^{2}\end{array}$ & $\begin{array}{c}\mathrm{E}_{\mathrm{f}}^{(2)} \\
\mathrm{N} / \mathrm{mm}^{2}\end{array}$ & $\begin{array}{c}\varepsilon_{\mathrm{u}}^{(2)} \\
\%\end{array}$ & $\begin{array}{l}\mathrm{W}^{(1)} \\
\mathrm{g} / \mathrm{m}^{2}\end{array}$ & $\begin{array}{l}\mathrm{t}^{(1)} \\
\mathrm{mm}\end{array}$ \\
\hline \multirow{3}{*}{ Steel } & UNIRM3 & 2474 & 207000 & 2.30 & 3186 & 192857 & 1.61 & 2110 & 0.256 \\
\hline & UMINHO & 3200 & 206000 & - & 3070 & 190000 & 1.62 & 1800 & 0.227 \\
\hline & TECNALIA & 3200 & 206000 & - & 3165 & 170000 & 2.20 & 600 & 0.075 \\
\hline Carbon & UNIRM3 & 4800 & 240000 & 1.80 & 1914 & 189361 & 1.18 & 168 & 0.047 \\
\hline Basalt & TECNALIA & 2100 & 89000 & 3.10 & 1160 & 67000 & 1.91 & 235 & 0.035 \\
\hline
\end{tabular}

A pozzolan-cement mortar used by UNIRM3, specifically designed for use with fibre meshes; the 28-days' compressive strength and the Young's modulus of 
the mortar were derived from five $50 \mathrm{~mm}$ cubic specimens. Solid clay bricks were used for bond testing, their properties deriving from compression tests on five 50 mm cubic specimens. Both steel and carbon meshes were used; the former was a commercial tape-like product consisting of high carbon steel cords unidirectionally oriented, having 12 cords/inch $(2.11 \mathrm{~mm}$ spacing between cords, designated by the producer as 'medium density'). The carbon fibre mesh was a balanced textile comprising $4 \mathrm{~mm}$ wide carbon fibre rovings arranged in two orthogonal directions at a net spacing of $6 \mathrm{~mm}$.

Solid clay bricks with dimensions of $200 \mathrm{~mm} \times 100 \mathrm{~mm} \times 50 \mathrm{~mm}$ were used at UMINHO for bond tests. The compressive strength of the bricks was characterized through compressive tests on six $40 \mathrm{~mm}$ cubic specimens, in the flatwise direction. A commercial 'medium density' steel mesh (12 cords/inch) was used as the reinforcement inserted in a pozzolan lime-based mortar with a compressive strength much lower than that used at UNIRM3, which contained cement, and a comparable Young's modulus. The mortar was characterized by performing compressive tests on five cylindrical specimens with $50 \mathrm{~mm}$ diameter and $100 \mathrm{~mm}$ height at 28 days.

TECNALIA laboratory used basalt fibre and steel wire meshes. Basalt textile was a balanced bi-directional grid comprising bitumen-coated fibre bundles. Basalt textile grid spacing was $20 \mathrm{~mm} \times 20 \mathrm{~mm}$, while steel wire fabric had a density of 4 cords/inch $(6.35 \mathrm{~mm}$ spacing between cords, designated by the producer as 'low density'). A cementitious mortar was used containing less than $4 \%$ of organic resins. After a 28 -day curing period, five $40 \mathrm{~mm} \times 40 \mathrm{~mm} \times 160 \mathrm{~mm}$ prisms were tested to determine the compressive strength and the Young's modulus of the mortar. Stone units were used for bond testing, whose compressive strength and Young's modulus were derived by means of five compression tests on $50 \mathrm{~mm}$ cubic specimens.

\section{TENSILE TESTS}

Despite the ultimate load may be sometimes difficult to be exploited, the tensile behaviour of EBRs may be important in some structural applications, such as shear reinforcement of masonry panels, extrados strengthening of arches and vaults, and confinement of columns. For this reason, direct tensile tests are required by standard codes (CNR, 2012; ICC, 2013) for the mechanical characterization of mortar-based reinforcement systems and are expected to become a fundamental step of product qualification process. Besides the maximum attainable stress, tensile tests also provide the Young's modulus of the composite, which is a key property for the reinforcement design, and the matrixto-textile bond properties, which significantly affect cracking, thus influencing adhesion to the substrate and durability.

An overview of the tensile tests is shown in Table 3, in which the size of the specimens and the number of textile layers embedded in the mortar are also listed. UNIRM3 performed tests on CTRM and SRG specimens having an overall cross section of $40 \mathrm{~mm} \times 7 \mathrm{~mm}$ and a length of $800 \mathrm{~mm}$ and $700 \mathrm{~mm}$, respectively. Tests were carried out after 28 days of curing by means of a universal MTS testing machine, equipped with a $500 \mathrm{kN}$ hydraulic actuator, under displacement control at $0.005 \mathrm{~mm} / \mathrm{s}$ rate (machine compliance $<0.05 \%$ ). The applied load was 
measured by a load cell integrated in the testing machine, while the strains were recorded through resistive strain gauges (having length of $10 \mathrm{~mm}$ and $0.07 \%$ precision), positioned vertically, parallel to each other, and applied directly on the fibres. For SRG specimens, in order avoid the detachment of the strain gauges from the steel cords, a small portion of the textile was impregnated with polymeric resin. This was not necessary for CTRM specimens, as the strain gauge and the carbon yarn had approximately the same width $(4 \mathrm{~mm})$. In multi-layer CTRM specimens, strain gauges have been applied to the intermediate layer in order to record a local measure of the strain in the reinforcement. It should however be considered that the strain distribution among layers may display slight differences.

The SRG specimens tested at UMINHO had a $3 \mathrm{~mm}$ mortar cover on each side of the steel cords resulting in a total thickness of $6 \mathrm{~mm}$. Monotonic tests were performed after 28 days of curing using a universal testing machine with a maximum load capacity of $200 \mathrm{kN}$, under displacement control at $0.033 \mathrm{~mm} / \mathrm{s}$ rate (machine compliance $<0.2 \%$ ). The applied load was recorded by a load cell integrated in the testing machine, while deformation was monitored by a clip gauge placed mid-height on the specimens. Finally, TECNALIA manufactured specimens with a $100 \mathrm{~mm} \times 10 \mathrm{~mm}$ cross section area and $600 \mathrm{~mm}$ length. The ends of each specimen were reinforced with two additional layers of textile (extending $200 \mathrm{~mm}$ from end to mid-height), in order to promote the failure of the specimen in its middle third portion. Tests were performed on a $100 \mathrm{kN}$ hydraulic testing machine, under displacement control at $0.008 \mathrm{~mm} / \mathrm{s}$ rate (machine compliance $<0.3 \%$ ) and load measurement precision better than $0.3 \%$. The deformation was measured by two LVDTs. According to current strengthening design practice, multi-layer reinforcement systems were tested for carbon and basalt textiles, as shown in Table 3 .

Table 3 Overview of the direct tensile tests on strengthening systems

\begin{tabular}{|c|c|c|c|c|c|c|}
\hline \multirow{2}{*}{ Institution } & \multicolumn{2}{|c|}{ Basalt } & Carbon & \multicolumn{2}{c|}{ Steel } & $\begin{array}{c}\text { Specimen } \\
\text { dimension } \\
{\left[\mathrm{mm}^{3}\right]}\end{array}$ \\
\cline { 2 - 7 } & 2 layers & 3 layers & 3 layers & $\begin{array}{c}4 \\
\text { cords/inch }\end{array}$ & $\begin{array}{c}12 \\
\text { cords/inch }\end{array}$ & \begin{tabular}{c}
$40 \times 7 \times 800$ \\
\hline UNIRM3
\end{tabular} \\
\cline { 2 - 7 } & & & 4 & & 4 & $40 \times 7 \times 700$ \\
\hline UMINHO & & & & & 4 & $50 \times 6 \times 450$ \\
\hline TECNALIA & 7 & 7 & & 7 & & $100 \times 10 \times 600$ \\
\hline
\end{tabular}

Based on the specific properties of the specimens tested and on available laboratory facilities, different solutions were developed to ensure adequate clamping of the specimen, which is necessary to guarantee a uniform load transfer and avoid stress concentration in the gripping area (Fig. 1). UNIRM3 and UMINHO chose to leave each end of the specimen free of mortar and to apply aluminium tabs by means of a structural glue. Then, the tabs were clamped within the wedges of the testing machine. TECNALIA gripped the ends of the TRM specimens by means of a mechanical device made out of two steel plates having rough surfaces (knurl). 

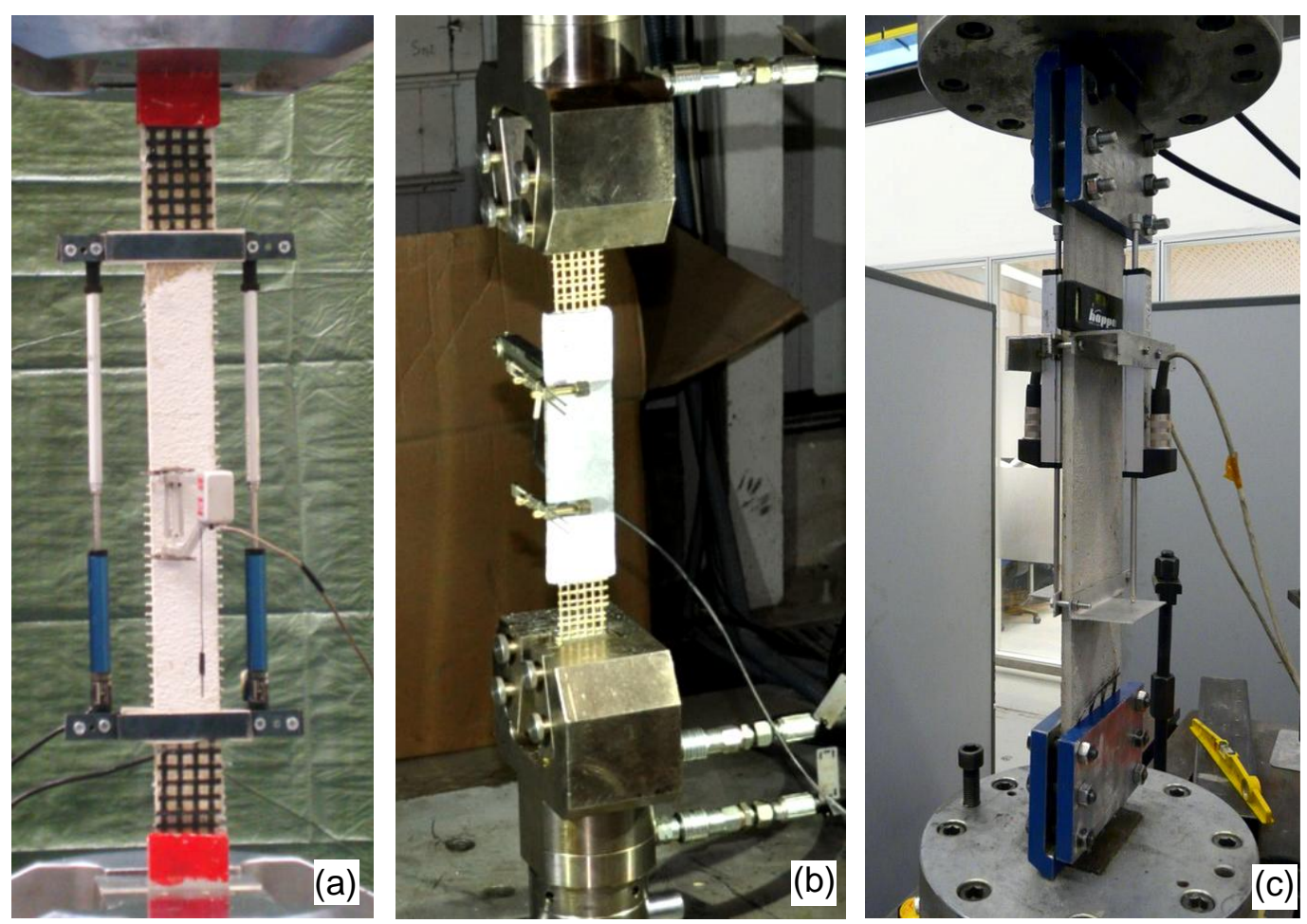

Fig. 1 Setup used for tensile tests by UNIRM3 (a), UMINHO (b) and TECNALIA (c)

The results of tensile tests are shown in Fig. 2a, Fig. 2b and Fig. 2c for SRG, CTRM, and BTRM, respectively. Stress values correspond to the applied load divided by the fibres' area. The latter is equal to the product of the number of layers, the specimen's width, and the textile design thickness in the direction of loading. The results (per mortar-based EBR) present a relatively low scatter, especially for what concerns the maximum tensile stress $\left(f_{t}\right)$, despite the differences in specimens' size and setups amongst different laboratories. Based on the present experimental investigation, higher strength values resulted from SRG specimens (in the order of $3000 \mathrm{~N} / \mathrm{mm}^{2}$ ), while BTRM and CTRM showed similar tensile resistance of about $1200 \mathrm{~N} / \mathrm{mm}^{2}$. The tensile strength of composite specimens was found to be close to that of the fabric, even if for CTRM a certain reduction was observed, probably related to local stress concentration. Misalignment of the textile layers (or of the rovings of the same textile layer), areas in between layers not adequately filled with mortar, wear of fibres at the vicinity of crack edges and non-uniform stress distribution within the textile are some of the reasons why the tensile strength of the composite may result lower than that of the textile (Häußler-Combe and Hartig, 2007). 

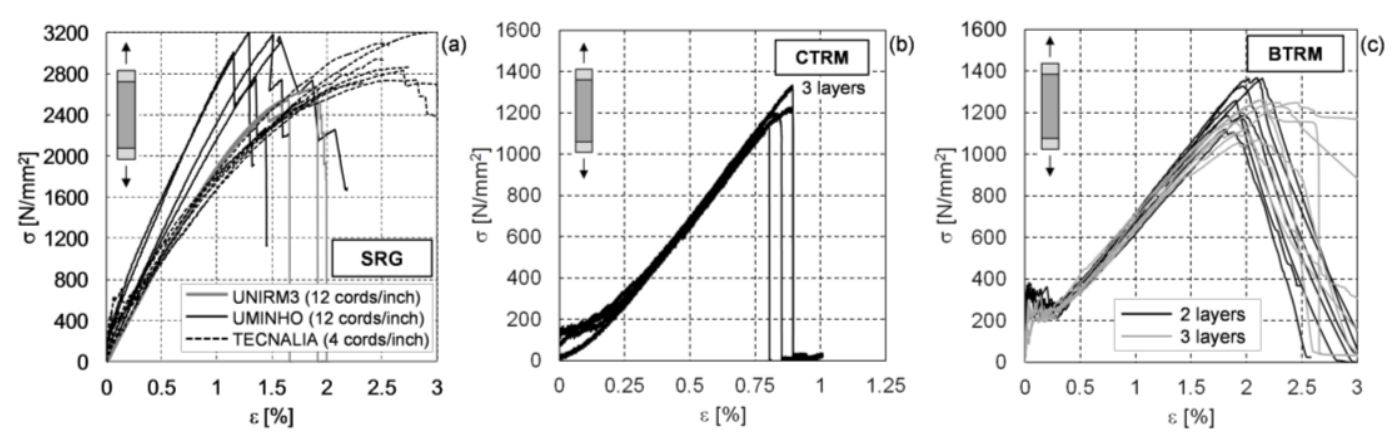

Fig. 2 Stress-strain curves of SRG (a), CTRM (b), and BTRM (c) specimens under uniaxial tension.

In the present case, the tensile strength and stiffness of BTRM was not strongly influenced by the number of textile's layers (Fig. 2c). The mechanical properties of mortar mainly affect the initial non-cracked behaviour, with negligible influence on the tensile strength and cracked stiffness of the composite. Conversely, the mortar plays a very important role in the bond mechanism as shown in the next section.

As for the ultimate strain $\left(\varepsilon_{\mathrm{u}}\right)$, i.e., the strain corresponding to the maximum stress, it was between $1 \%$ and $2 \%$ for SRG with higher density (12 cords/inch) and about $2.5-3 \%$ for SRG with lower density (4 cords/inch), about $0.8 \%$ for CTRM and, finally, about $2 \%$ for BTRM. The latter also showed a lower stiffness of about $6 \times 10^{4} \mathrm{~N} / \mathrm{mm}^{2}$, due to the lower Young's modulus of the basalt filaments.

Similarly to TRC (Brameshuber, 2006; Cuypers and Wastiels, 2006), three response stages are observable in the stress-strain curves (Fig. 2c). The first stage corresponds to the behaviour of the uncracked specimen. When the tensile strength of the mortar is reached the first crack is formed and the second stage, the multiple cracking one, starts. The length of the multiple cracking stage was reduced with a higher number of reinforcement layers, as also observable in reinforced concrete (Cuypers and Wastiels, 2006). In the third stage (postcracking stage during which the crack pattern has been stabilized), the composite is stressed up to the strength of the textile. The stiffness of the post-cracking stage was found to be slightly lower than that of the textile if loaded independently; this is also reported by other studies (Brameshuber, 2006) and it is attributed to the premature failure of some filaments and to the premature debonding of either the core filaments (for textiles with uncoated rovings, Ohno and Hannant, 1994) or the coated rovings. When the remaining filaments cannot bear the applied load, their fracture causes the composite's rupture. As shown in Fig. 2a, failure of SRG specimens occurred as a progressive rupture of the cords, after a clear loss of linearity in the response curve. CTRM specimens displayed a brittle failure of the entire textile (Fig. 2b) while in BTRM specimens some sort of progressive (although very fast) deterioration is visible in the post-peak branches of the curves (Fig. 2c), which may be related to the textile unravelling within the matrix. The fundamental difference in the tensile behaviour of SRG with respect to CTRM and BTRM depends on the different structures of the reinforcement textiles. Steel cords are homogeneous, while carbon and basalt textiles are made out of bundles of filaments, such that only the external filaments directly interact with the mortar matrix, while the load transfer to the core ones relies on the friction/bond between filaments. A bond failure between filaments within a bundle (telescopic rupture) may be responsible of larger displacements in CTRMs and BTRMs. 
The results of all tensile tests are presented in Table 4, in which the Young's modulus $\left(\mathrm{E}_{\mathrm{t}}\right)$ of the composite specimens was obtained during the last stage (cracked specimen). Despite the fact that the matrix is cracked, the mortar between consecutive cracks still provides some stiffening effect and load redistribution amongst the yarns/cords of the textile.

Table 4 Mean values of the results of tensile tests (standard deviation in brackets)

\begin{tabular}{|c|c|c|c|c|}
\hline Reinforcement & Institution & $\begin{array}{c}\mathrm{f}_{\mathrm{t}} \\
{\left[\mathrm{N} / \mathrm{mm}^{2}\right]}\end{array}$ & $\begin{array}{c}\mathrm{E}_{\mathrm{t}} \\
{\left[\mathrm{N} / \mathrm{mm}^{2}\right]}\end{array}$ & $\begin{array}{c}\varepsilon_{\mathrm{u}} \\
{[\%]}\end{array}$ \\
\hline \multirow{4}{*}{ SRG } & UNIRM3 & $\begin{array}{c}2558 \\
(189)\end{array}$ & $\begin{array}{c}209805 \\
(10280)\end{array}$ & $\begin{array}{c}1.90 \\
(0.25)\end{array}$ \\
\cline { 2 - 5 } & UMINHO & $\begin{array}{c}3137 \\
(87)\end{array}$ & $\begin{array}{c}217500 \\
(20227)\end{array}$ & $\begin{array}{c}1.37 \\
(0.19)\end{array}$ \\
\cline { 2 - 5 } & TECNALIA & $\begin{array}{c}2959 \\
(192)\end{array}$ & $\begin{array}{c}150400 \\
(6960)\end{array}$ & $\begin{array}{c}2.76 \\
(0.21)\end{array}$ \\
\hline \multirow{2}{*}{ CTRM } & UNIRM3 & $\begin{array}{c}1191 \\
(106)\end{array}$ & $\begin{array}{c}196525 \\
(13756)\end{array}$ & $\begin{array}{c}0.74 \\
(0.07)\end{array}$ \\
\hline \multirow{2}{*}{ BTRM (2 layers) } & TECNALIA & $\begin{array}{c}1256 \\
(92)\end{array}$ & $\begin{array}{c}59000 \\
(3310)\end{array}$ & $\begin{array}{c}1.96 \\
(0.11)\end{array}$ \\
\hline \multirow{2}{*}{ BTRM (3 layers) } & TECNALIA & $\begin{array}{c}1195 \\
(77)\end{array}$ & $\begin{array}{c}57000 \\
(1840)\end{array}$ & $\begin{array}{c}2.10 \\
(0.20)\end{array}$ \\
\hline
\end{tabular}

Independently from the type of textile used, and from the mortar adopted as matrix, the crack development observed during tensile tests on mortar-based composites was characterized by the presence of cracks transversal to the direction of the applied load, clearly identifiable in the response curves and visible during testing at low stress values. The crack spacing and width were dependent on the type and quantity of reinforcement and on the textile-to-matrix bond behaviour. Higher fibres' volume fractions, as well as fibres with higher stiffness, gave rise to denser crack patterns. A larger number of narrow cracks developed in SRG specimens, which may be related to a better interlocking between cords and mortar. Improved bond conditions hinder slipping of the textile within the mortar and the development of few wide cracks. Transversal cracks sometimes developed in the vicinity of the aluminium tabs used to grip the samples, highlighting the importance of clamping in tensile testing. However, this was not evident for SRG specimens, probably due to the higher toughness of the material (improving its capacity for stress redistribution) and to the detachment of mortar induced by the transverse shortening of the steel cord tape, as well as for BTRM specimens, in which the end of the specimens were strengthened and cracks only appeared in their middle third (Fig. 3).
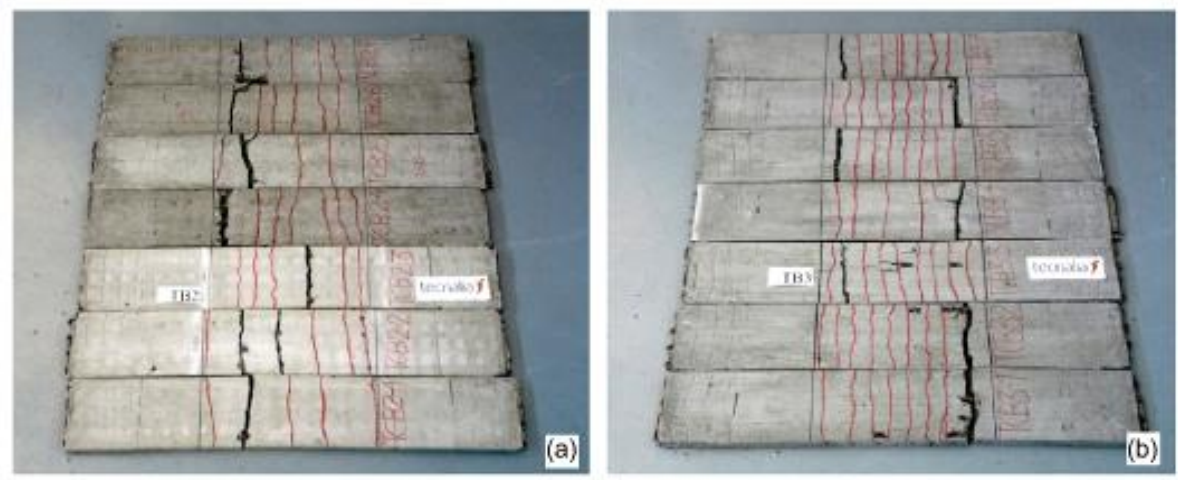

Fig. 3 Tensile tests on BTRM: development of the crack pattern in the middle third of the specimens on series TB2 with 2 layers (a) and TB3 with 3 layers (b) 


\section{BOND TESTS}

\subsection{Experimental programme and test setup}

Tests on bond performance were carried out on CTRM (with either 2 layers or 3 layers) and SRG on brick substrate, and on BTRM on stone substrate, as reported in Table 5. A standard wet lay-up procedure was followed to bond the steel, carbon or basalt textile sheets on either solid clay brick or stone substrates. The procedure involved the application of a 2-3 $\mathrm{mm}$ thick mortar layer on the block's surface (smoothing out any surface irregularities) and the subsequent bonding of the textile by hand and roller pressure. The textile was pressed slightly into the fresh mortar, which protruded through all the perforations between fibre rovings. The mortar was also applied in between layers (where applicable) and on top of the last textile layer. The total thickness was 6-7 mm. Curing was achieved in room conditions (about $15-20^{\circ} \mathrm{C}$ and $50-60 \%$ R.H.). In order to prevent premature slipping of the textile within the matrix, 2 layers of basalt and 3 layers of carbon were applied, as in tensile tests.

Drawing on previous experience on FRP (Valluzzi et al., 2012), four different shear bond testing setups were used: two single-lap (SL) and two double-lap (DL1 and DL2), as shown by Figs. 4 and 5. Very similar single-lap test schemes were used by UMINHO and TECNALIA, consisting of stiffened steel plates welded so as to form an angle of $90^{\circ}$ (Fig. 4). At UMINHO, the specimens were supported appropriately to avoid misalignments in the load application and were loaded from above (Fig 4a). Tests were carried out under displacement control at a rate of $0.005 \mathrm{~mm} / \mathrm{s}$. The load was measured by a load cell while the relative displacement between the reinforcement and the brick was measured by means of two LVDTs mounted at the loaded end. At TECNALIA, the specimens rested on the bottom of the steel frame and the reinforcement sheet was loaded from below (Fig. 4b). Tests were performed using a $5 \mathrm{kN}$ Lloys Universal Testing machine under displacement control at $0.008 \mathrm{~mm} / \mathrm{s}$ rate. Displacements were recorded by LVDTs fixed at the main frame of the testing machine and measuring the relative displacement between aluminium squares stuck to the mortar on bonded and unbonded areas. 

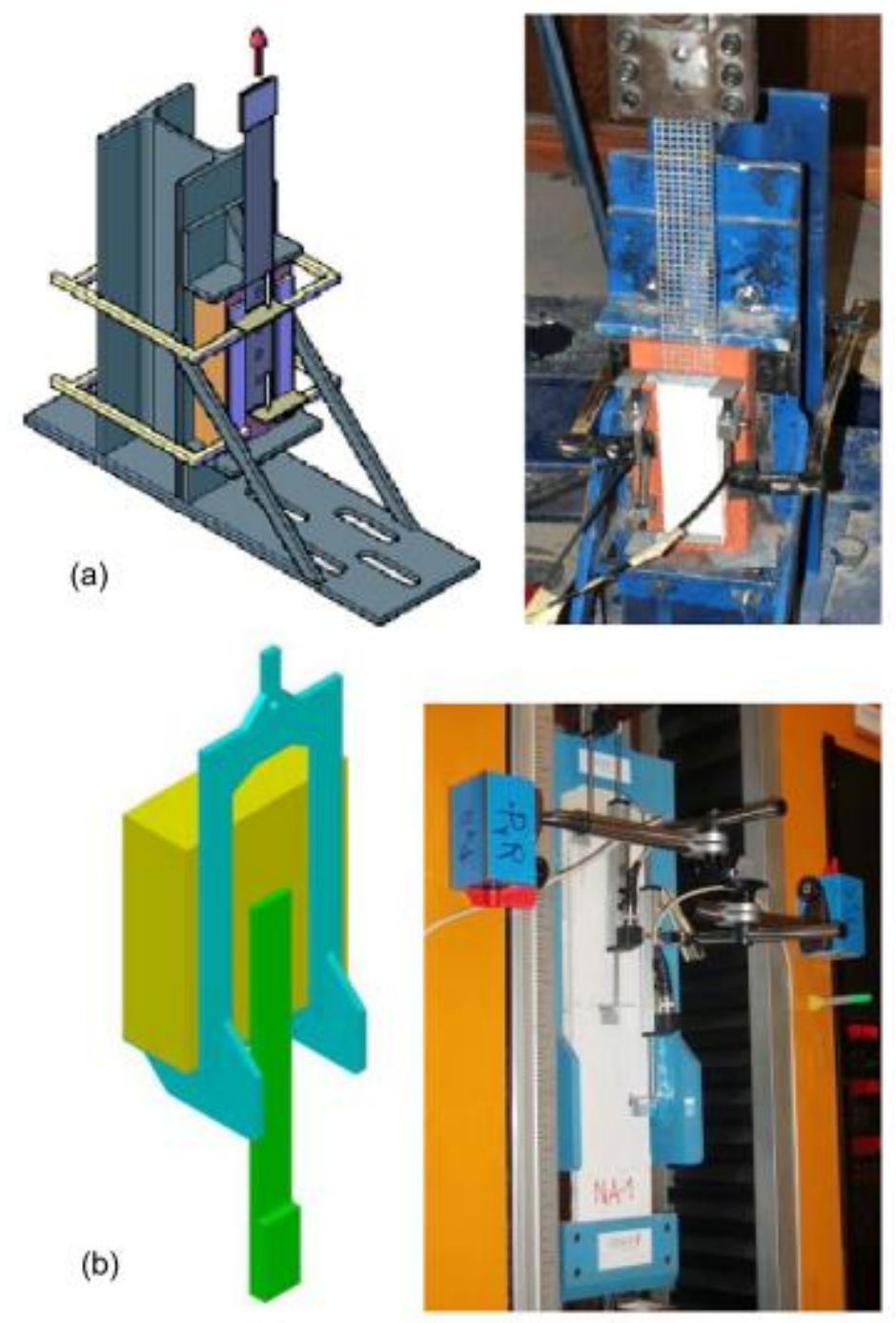

Fig. 4 Single-lap (SL) setup for bond shear tests carried out at UMINHO (a) and TECNALIA (b) 

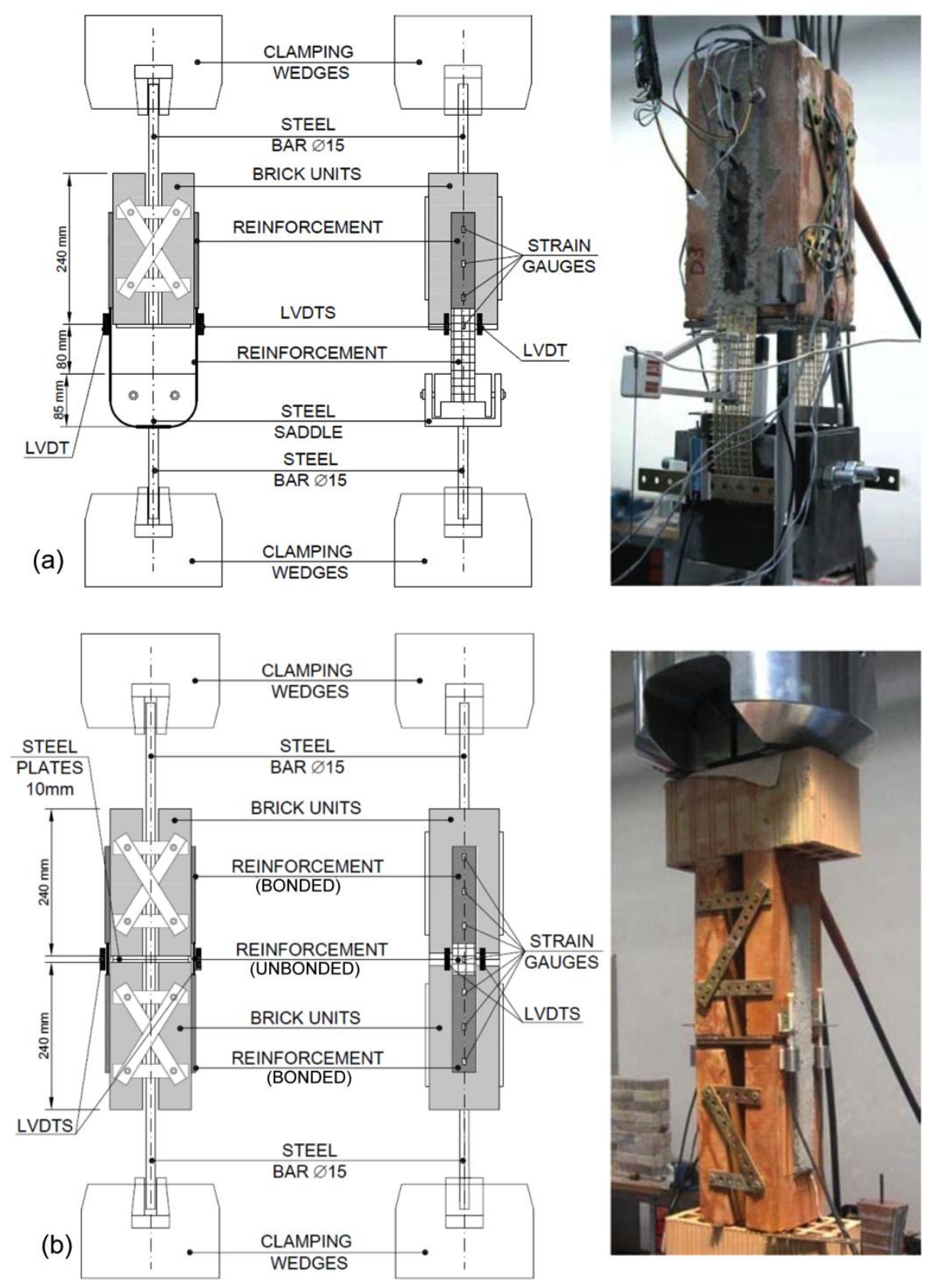

Fig. 5 Double lap setup for shear bond tests: type 1 (DL1, a) and type 2 (DL2, b)

UNIRM3 used double lap setups (DL). Specimens were built by joining together two bricks, placed parallel to each other; the reinforcement was then applied on both external faces. Setup DL1 (Fig. 5a) consisted of two or four bricks (depending on the anchorage length) pulled by the testing machine in one direction (upwards in the present case) through a steel bar welded to a steel plate (on which the bricks rested), while a continuous U-shaped reinforcement strip was pulled in the other direction (downwards) by means of a semi-circular steel saddle, having a diameter equal to the specimen width to apply pure shear stresses on the brick-reinforcement interface. In test setup DL2 (Fig. 5b) specimens were made out of four bricks. Two bricks were pulled upwards while the other two were pulled downwards. Two separate strengthening strips were applied on the external faces so as to connect two bricks by crossing the gap between them. In UNIRM3 tests were performed by using a $500 \mathrm{kN}$ MTS Universal Testing 
machine under displacement control at $0.005 \mathrm{~mm} / \mathrm{s}$ rate. The load was recorded by a load cell integrated in the testing machine, while four LVDTs with $10 \mathrm{~mm}$ stroke and $0.05 \mathrm{~mm}$ sensitivity were used to record relative displacements between reinforcement sheets and brick substrate. Finally, a set of $2.5 \mathrm{~mm}$ long strain gauges was applied directly on the fibres, on both sides of the specimen to record local strain values along the reinforcement strip. Furthermore, a reinforcement band was left unbonded for a length of $10 \mathrm{~mm}$ from the tip of the sample in order to avoid local stress concentrations induced by boundary effects.

Aiming at investigating the effect of the anchorage length on the ultimate load and at determining the effective anchorage length (defined as that necessary for a complete stress transfer between reinforcement and substrate), various anchorage lengths were used, ranging from $55 \mathrm{~mm}$ to $440 \mathrm{~mm}$, as reported in Table 5, listing all the tests performed. Two different substrate preparation techniques were also experimented on SRG; the first was minimal and involved cleaning and dusting the brick's surface while the second employed by sand-blasting.

The experimental investigation made it possible to detect the overlay-tosubstrate shear bond failure mode for the different textiles and anchorage lengths investigated as well as to derive the global response in terms of load vs. displacement relationships. Finally, the strain profile along the reinforcement strip, recorded for SRG and CTRM specimens, gave some indication on the activation and propagation of the debonding phenomena and on the effective anchorage length.

\subsection{Failure modes}

Three failure modes were observed: debonding at substrate-matrix interface (a), debonding at the textile-matrix interface (b) and slipping of the cords or rovings from the matrix (c), as sketched in Fig. 6. In the latter case the weak surface is the interface between the cords or rovings of the reinforcement textile and the mortar matrix they are embedded in.
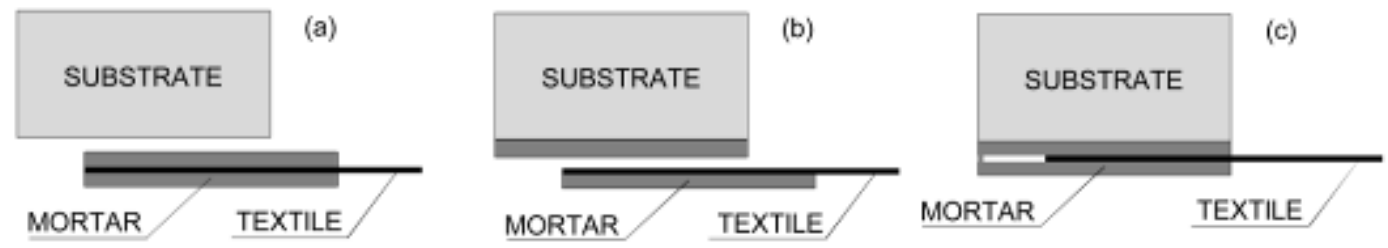

Fig. 6 Failure modes: debonding at substrate-matrix interface and peeling of the brick surface (a), debonding at textile-matrix interface (b) and slipping of the textile from the matrix (c)

Differently from strengthening systems based on polymeric resins, mortarbased systems generally suffered a failure within the reinforcement, without involving the substrate. In SRG specimens the failure mode (a) generally occurred with the shortest $(55 \mathrm{~mm})$ anchorage length (Fig. 7a); this observation comes into agreement with the findings of previous experimental studies on concrete (Matana et al., 2005), thus indicating that shorter anchorage lengths, in addition to shear stress (Mode II), may induce normal stress at the mortar-substrate interface (Mode I), due to the misalignment between this interface and the textile. These normal stresses are responsible for the extraction of aggregates from the grout (ripping) observed in the failure mode of specimens with shorter anchorage lengths. 
Moreover the effective length of Mode I is much less than that of Mode II and therefore a short joint is very sensitive to Mode I. A cohesive failure by debonding at the textile-matrix interface (mode b) was observed with the longest anchorage lengths (220 mm and $440 \mathrm{~mm}$ ), as shown in Fig. 7b. The results of the tests performed on SRG showed that the surface preparation may significantly affect the failure mode. In the brick specimens with minimal surface preparation, the mortar detached from the brick surface (failure mode (a), Fig. 7c), while steel cord slipping with mortar cover separation was observed in the sand-blasted specimens (combined failure mode (b-c), Fig. 7d).

In the case of BTRM, debonding at the substrate-mortar interface was observed for the shortest anchorage length ( $85 \mathrm{~mm}$, Fig. 8a), while failure by slipping of the textile within the matrix (mode c) occurred for the longest anchorage lengths (150mm and $220 \mathrm{~mm}$, Fig. 8b).
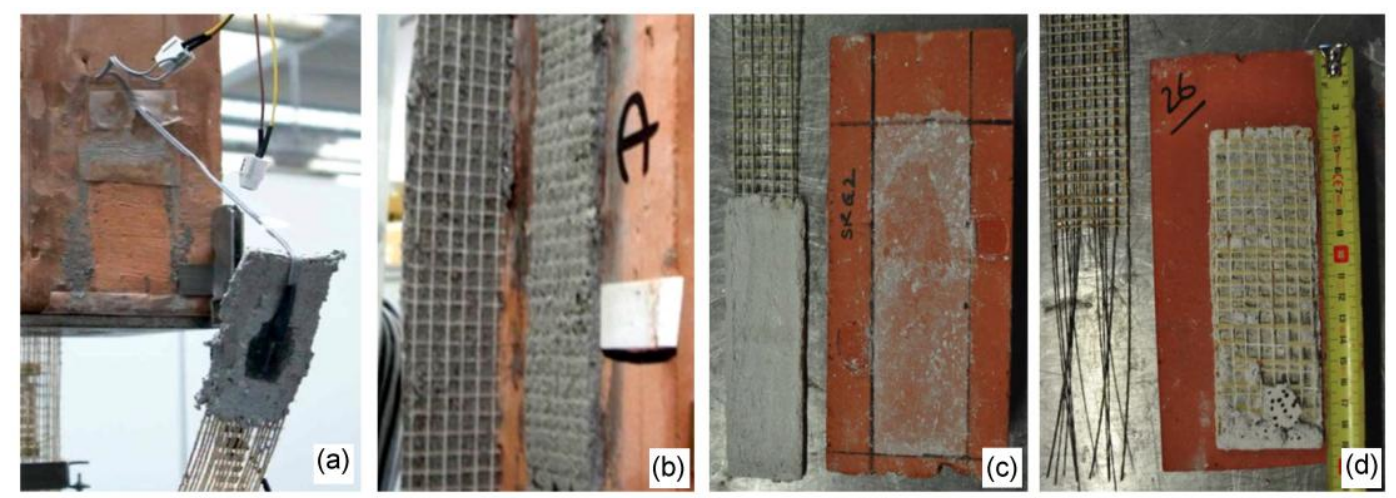

Fig. 7 Failure modes in SRG specimens. Effect of anchorage length: debonding at the substrate-matrix interface in specimens with anchorage length of $55 \mathrm{~mm}$ (a) and at the textile-matrix interface in specimens with anchorage length of $220 \mathrm{~mm}$ (b) (all specimens received minimal surface preparation prior to SRG application). Effect of surface preparations: specimens with minimal preparation (c) and with sand-blasted surface (d)
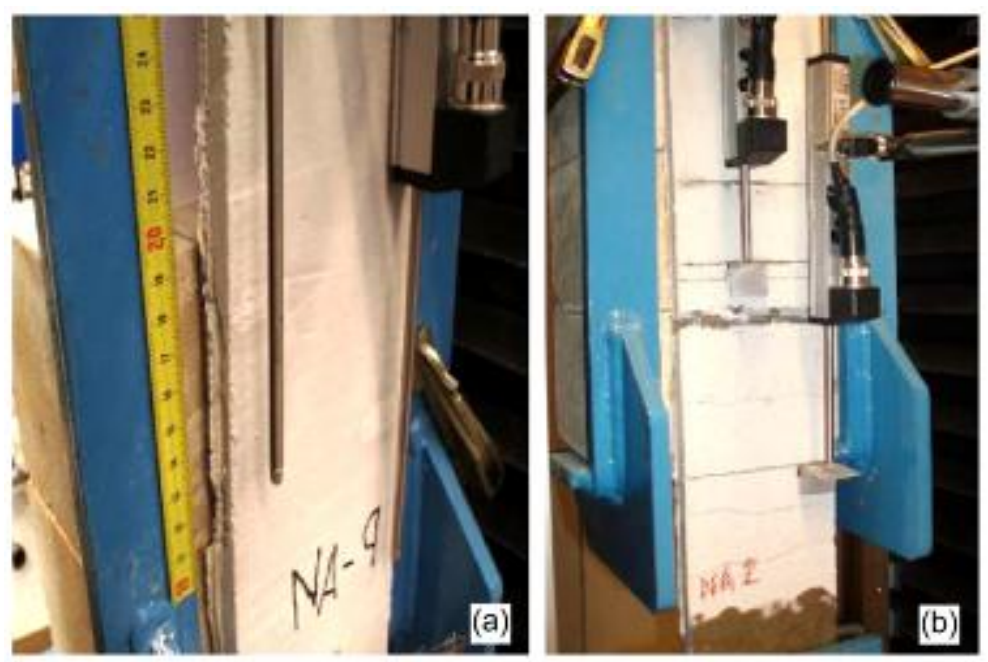

Fig. 8 Failure modes in BTRM specimens: debonding at the substrate-matrix interface in specimens with anchorage length of $85 \mathrm{~mm}$ (a) and slipping of the fibre rovings from the matrix in specimens with anchorage length of $220 \mathrm{~mm}$ (b) 
In CTRM, the fibre-matrix interface generally resulted to be the weakest link; sliding of the fibre within the matrix (failure mode c) was observed in the specimens with the shortest anchorage lengths $(55 \mathrm{~mm}$ and $110 \mathrm{~mm})$, as shown by Figs. 9a,b while debonding at the fibre-matrix interface occurred for the longest one $(220 \mathrm{~mm})$. Intermediate anchorage lengths $(165 \mathrm{~mm})$ gave rise to a combined failure mode consisting in an initial partial debonding of the matrix until the development of a transversal crack, and in the subsequent sudden sliding of the fibre within the matrix inducing a brittle failure (Figs.9c,d).
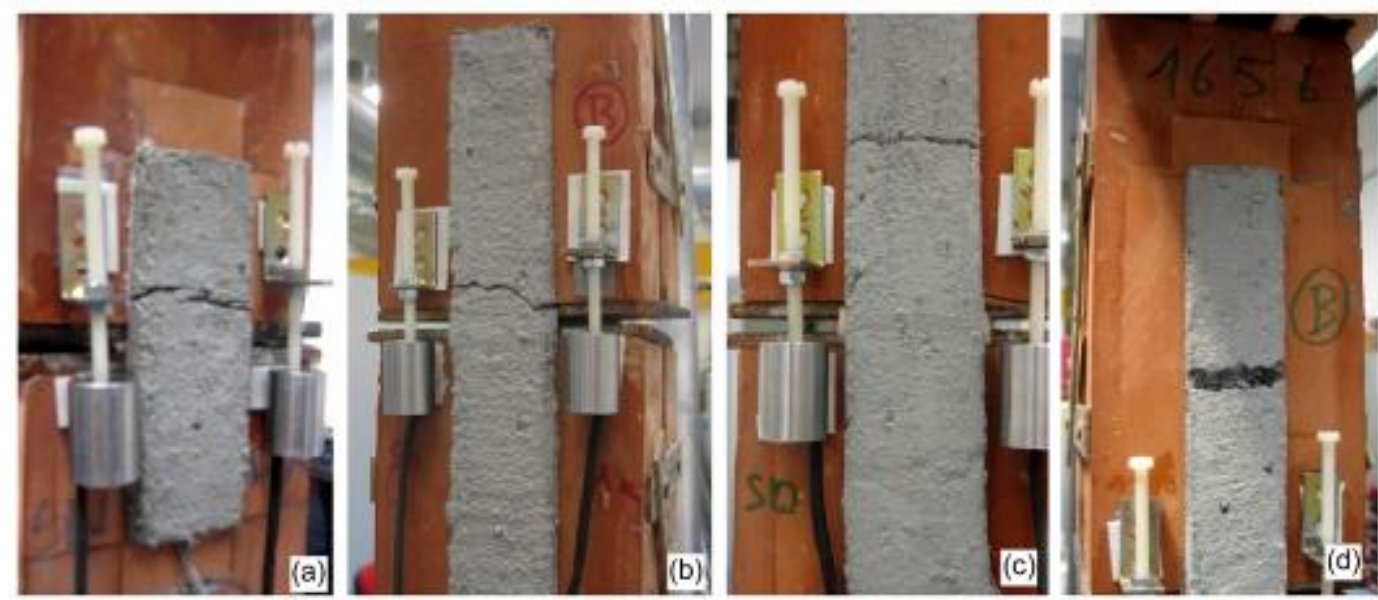

Fig. 9 Failure modes in CTRM specimens: slipping of the fibre rovings from the matrix in specimens with anchorage length $55 \mathrm{~mm}$ (a) and $110 \mathrm{~mm}$ (b) and combined failure with initial debonding of the matrix and subsequent slipping of the fibre rovings from the matrix in specimens with anchorage length $165 \mathrm{~mm}(\mathrm{c}, \mathrm{d})$

\subsection{Results}

The global response of the reinforcement-substrate systems under shear loads is represented by $\mathrm{F}-\delta$ curves, $\mathrm{F}$ being the load applied on the reinforcement strip, and $\delta$ the relative displacement between reinforcement and substrate. In DL setups the determination of the force applied on one side of the specimens required the distribution of the load resultant amongst the two reinforcement strips to be known. Despite the symmetry of the specimen and the setup, most of the times strains and displacement were higher on the side where failure occurred, especially when DL1 was used. Apart from the intrinsic variability of bond quality (due to a certain randomness in the degree of mortar protrusion through the reinforcement's openings) such a non-uniform load distribution is likely to be related to the unavoidable small asymmetries, settlements and adjustments of the steel plates and of the bricks (which may not be perfectly aligned to each other). In order to estimate the distribution of the load on the two sides of the specimen, one strain gauge per side was placed on the unbonded area of the textile (impregnated with polymeric resin), providing a local measure of the load, given the Young's modulus of the fibres. The load's distribution was taken to be proportional to the ratio of the strains measured by the strain gauges.

The ultimate load of the bond tests carried out within the present experimental campaign are plotted in Fig. 10, having the anchorage length on the $\mathrm{x}$-axis and the ultimate load divided by the width of the reinforcement strip on the y-axis. The exploitation of fibre strength (i.e., ratio between debonding load and tensile failure 
load of the composite) is also included in Table 5. For bonded length longer than the effective one, the exploitation ratio was found to be higher for carbon textile (up to more than 90\%) with respect to steel (about 25-30\% when applied with cement mortar), and to basalt (up to $40 \%$ ).

Table 5 Results of bond tests

\begin{tabular}{|c|c|c|c|c|c|c|c|c|}
\hline Substrate & Fibre & Mortar & Setup & $\begin{array}{c}\text { Anchorage } \\
\text { Length } \\
{[\mathrm{mm}]}\end{array}$ & $\begin{array}{l}\text { Width } \\
{[\mathrm{mm}]}\end{array}$ & $\begin{array}{c}\text { Ultimate } \\
\text { Load } \\
{[\mathrm{N}]}\end{array}$ & $\begin{array}{l}\text { Exploitation of } \\
\text { fibre strength }\end{array}$ & $\begin{array}{l}\text { Failure } \\
\text { mode }\end{array}$ \\
\hline \multirow{34}{*}{ Brick } & \multirow{14}{*}{$\begin{array}{l}\text { Carbon } \\
\text { (3 layers) }\end{array}$} & \multirow{26}{*}{$\begin{array}{l}\text { Fibre- } \\
\text { reinforced } \\
\text { cement- } \\
\text { based }\end{array}$} & \multirow{6}{*}{ DL1 } & 55 & 40 & 3420 & $50.9 \%$ & $\mathrm{c}$ \\
\hline & & & & 55 & 40 & 3010 & $44.8 \%$ & $\mathrm{~b}$ \\
\hline & & & & 220 & 40 & 4180 & $62.2 \%$ & $a-c$ \\
\hline & & & & 220 & 40 & 5290 & $78.8 \%$ & $a-c$ \\
\hline & & & & 220 & 40 & 6110 & $91.0 \%$ & $a-c$ \\
\hline & & & & 220 & 40 & 5010 & $74.6 \%$ & $a-c$ \\
\hline & & & \multirow{8}{*}{ DL2 } & 55 & 40 & 3880 & $57.8 \%$ & $\mathrm{c}$ \\
\hline & & & & 55 & 40 & 4260 & $63.4 \%$ & $\mathrm{c}$ \\
\hline & & & & 110 & 40 & 5020 & $74.7 \%$ & $\mathrm{c}$ \\
\hline & & & & 110 & 40 & 4610 & $68.6 \%$ & $\mathrm{c}$ \\
\hline & & & & 165 & 40 & 5190 & $77.3 \%$ & $\mathrm{c}$ \\
\hline & & & & 165 & 40 & 5700 & $84.9 \%$ & $a-c$ \\
\hline & & & & 220 & 40 & 6590 & $98.1 \%$ & $\mathrm{a}$ \\
\hline & & & & 220 & 40 & 5830 & $86.8 \%$ & $\mathrm{~b}$ \\
\hline & \multirow{20}{*}{$\begin{array}{c}\text { Steel } \\
\text { (1 layer) }\end{array}$} & & \multirow{12}{*}{ DL2 } & 55 & 40 & 4870 & $18.6 \%$ & $\mathrm{a}$ \\
\hline & & & & 55 & 40 & 4080 & $15.6 \%$ & $\mathrm{a}$ \\
\hline & & & & 55 & 40 & 3630 & $13.9 \%$ & $\mathrm{a}$ \\
\hline & & & & 220 & 40 & 7610 & $29.1 \%$ & $\mathrm{~b}$ \\
\hline & & & & 220 & 40 & 6760 & $25.8 \%$ & $\mathrm{~b}$ \\
\hline & & & & 220 & 40 & 6270 & $23.9 \%$ & $\mathrm{~b}$ \\
\hline & & & & 220 & 40 & 6370 & $24.3 \%$ & $\mathrm{~b}$ \\
\hline & & & & 220 & 40 & 6360 & $24.3 \%$ & $\mathrm{~b}$ \\
\hline & & & & 220 & 40 & 6460 & $24.7 \%$ & $\mathrm{~b}$ \\
\hline & & & & 440 & 40 & 7780 & $29.7 \%$ & $\mathrm{~b}$ \\
\hline & & & & 440 & 40 & 7030 & $26.8 \%$ & $a-b$ \\
\hline & & & & 440 & 40 & 7590 & $29.0 \%$ & $\mathrm{~b}$ \\
\hline & & \multirow{8}{*}{$\begin{array}{l}\text { Lime- } \\
\text { based }\end{array}$} & \multirow{4}{*}{ SL } & 150 & 50 & 1470 & $4.1 \%$ & $\mathrm{a}$ \\
\hline & & & & 150 & 50 & 1620 & $4.6 \%$ & $\mathrm{a}$ \\
\hline & & & & 150 & 50 & 1230 & $3.5 \%$ & $\mathrm{a}$ \\
\hline & & & & 150 & 50 & 1580 & $4.4 \%$ & b-c \\
\hline & & & \multirow{4}{*}{$\begin{array}{c}\mathrm{SL} \\
\text { sandblasted }\end{array}$} & 150 & 50 & 2970 & $8.3 \%$ & $b-c$ \\
\hline & & & & 150 & 50 & 2300 & $6.5 \%$ & $b-c$ \\
\hline & & & & 150 & 50 & 2870 & $8.1 \%$ & b-c \\
\hline & & & & 150 & 50 & 3700 & $10.4 \%$ & b-c \\
\hline \multirow{9}{*}{ Stone } & \multirow{9}{*}{$\begin{array}{c}\text { Basalt } \\
\text { (2 layers) }\end{array}$} & \multirow{9}{*}{$\begin{array}{l}\text { Cement- } \\
\text { based } \\
\text { polymer } \\
\text { modified }\end{array}$} & \multirow{9}{*}{ SL } & 85 & 100 & 2810 & $32.0 \%$ & $\mathrm{a}$ \\
\hline & & & & 85 & 100 & 3160 & $35.9 \%$ & $\mathrm{a}$ \\
\hline & & & & 85 & 100 & 2380 & $27.1 \%$ & $\mathrm{a}$ \\
\hline & & & & 85 & 100 & 1840 & $20.9 \%$ & $\mathrm{a}$ \\
\hline & & & & 85 & 100 & 2380 & $27.1 \%$ & $\mathrm{a}$ \\
\hline & & & & 150 & 100 & 3080 & $35.0 \%$ & $\mathrm{c}$ \\
\hline & & & & 150 & 100 & 2770 & $31.5 \%$ & $\mathrm{c}$ \\
\hline & & & & 200 & 100 & 3690 & $42.0 \%$ & $\mathrm{c}$ \\
\hline & & & & 200 & 100 & 2700 & $30.7 \%$ & $\mathrm{c}$ \\
\hline
\end{tabular}




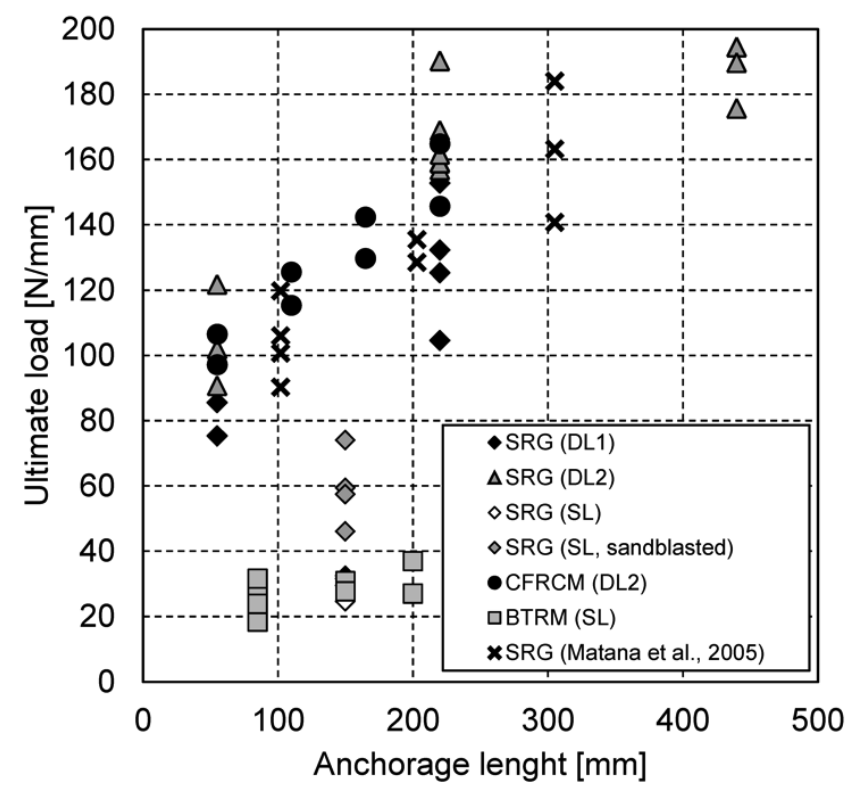

Fig. 10 Ultimate load per unit width vs. anchorage length

The global F- $\delta$ curves are plotted in Figs. 11a, 11b, and 11c. SRG showed higher bond strength (up to $190 \mathrm{~N} / \mathrm{mm}$ for longer bonded length) and stiffness, with maximum displacement in the order of $0.2-0.6 \mathrm{~mm}$. The lower strength displayed by the tests on SRG with $150 \mathrm{~mm}$ anchorage length is to be attributed to the lower resistance of the mortar, thus indicating the strong effect of the matrix on the debonding load. The comparison between tests on SRG carried out with the same mortar but different surface preparation procedures show the considerable effect of the surface preparation on the debonding load, which was on average $59.2 \mathrm{~N} / \mathrm{mm}$ for specimens with sandblasted surface, and $29.5 \mathrm{~N} / \mathrm{mm}$ for untreated bricks.

CTRM exhibited bond strength of about 140-160 N/mm and maximum displacements of about $1 \mathrm{~mm}$. No significant differences were observed between DL1 and DL2 setup schemes; although setup configuration DL2 was found to guarantee a better symmetry in load transfer.
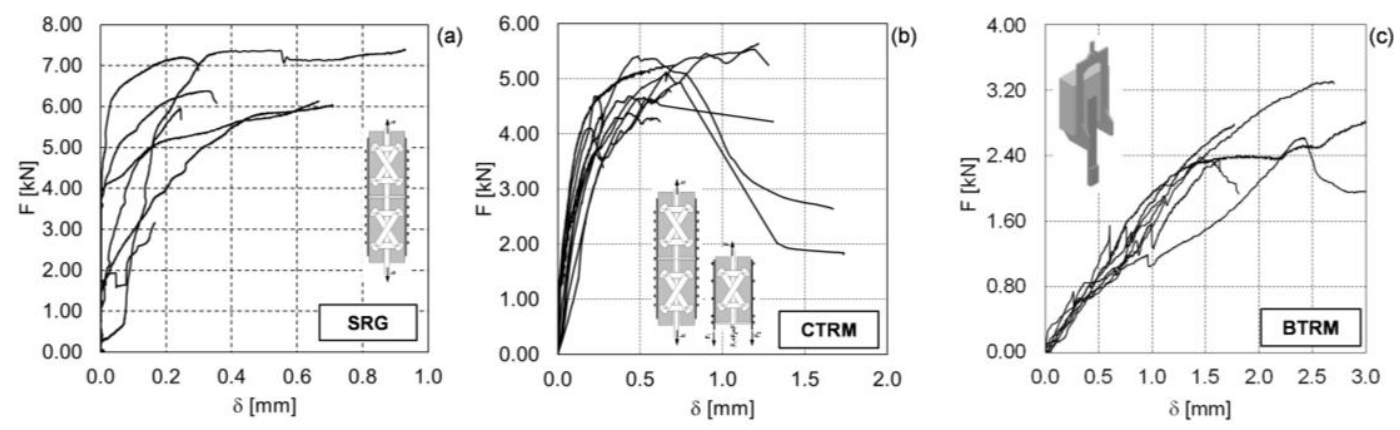

Fig. 11 Load-displacement curves for SRG (a) and CTRM (b) on brick substrates, and for BTRM (c) reinforcement on stone substrates

Finally, BTRM applied on stone substrate showed lower bond strength (in the order of 20-40 N/mm) and higher deformability (displacements of about $2 \mathrm{~mm}$ were reached) with respect to the other reinforcement types, due to the lower stiffness of both the textile and the mortar matrix. The larger displacements 
recorded in carbon and basalt reinforcements are also related to the slippage of the textile within the mortar matrix during the debonding process especially in those specimens displaying failure mode (c).

Data recorded by the strain gauges have been used to obtain strain profiles (i.e., strain vs. sensor position relation), as shown by Fig. 12, in which each curve refers to a different load level (F) ranging from $20 \%$ to $100 \%$ of the ultimate load $\left(\mathrm{F}_{\mathrm{u}}\right)$. At this latter load level, three curves are represented, which correspond to the strain values recorded during delamination. Under low force values, strains were detected only in the vicinity to the loaded end and the higher was the applied load the larger was the length of the involved reinforcement strip. In SRG, as long as the load was below $40 \%$ of the maximum value, the length of the reinforcement involved in the stress transmission was ca. $80 \mathrm{~mm}$ and the strains were in the order of $1.5 \times 10^{-3}$. Then, as the load increased, the strain of the fibres increased until a maximum value of about $3.5 \times 10^{-3}$. The length of reinforcement involved in the stress transmission area was about $150 \mathrm{~mm}$ as revealed by the strain profiles of all the curves, with the exception of the last four lines (corresponding to $\mathrm{F}=80 \%$ $\mathrm{F}_{\mathrm{u}}$ and $\mathrm{F}=100 \% \mathrm{~F}_{\mathrm{u}}$ ) in the bottom edge of the specimen, which may be related to an initial debonding of the reinforcement on this side.
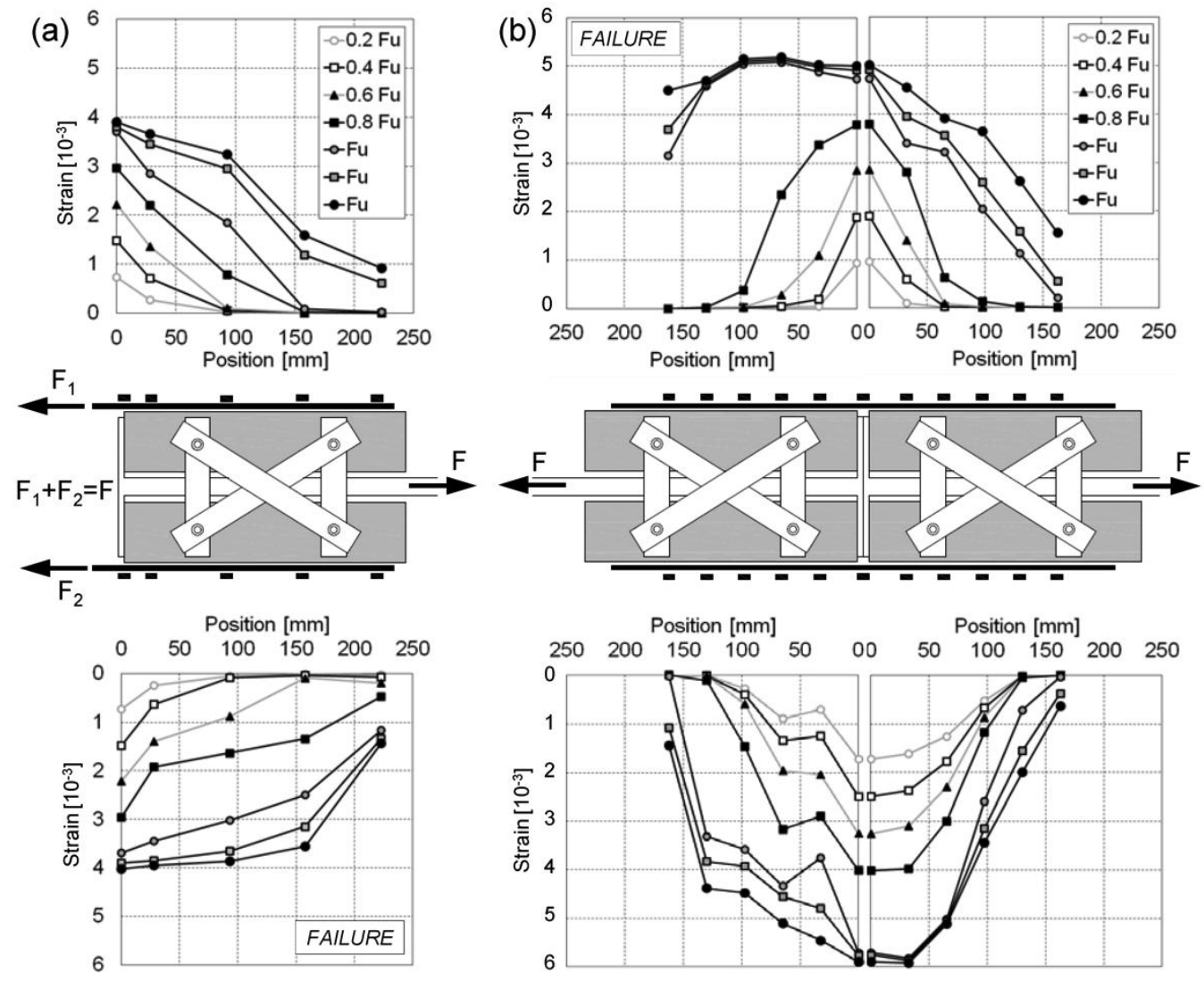

Fig. 12 Strain profiles for SRG (a) and CTRM (b) reinforcements

Concerning CTRM, the maximum strains where about $4 \times 10^{-3}$ (at least as long as the load was below $80 \% \mathrm{~F}_{\mathrm{u}}$ ) while the involved length was never higher than $150 \mathrm{~mm}$ with the exception of the last three curves (corresponding to $\mathrm{F}=100 \% \mathrm{~F}_{\mathrm{u}}$ ).

The shape of the strain profiles clearly displayed a variation in the concavity indicating the activation and subsequent development of debonding failure. Once such a phenomenon was activated, the strain recorded by the gauges located in the 
vicinity of the specimen edge reached a maximum value (in the order of $3-4 \times 10^{-3}$ and $5-6 \times 10^{-3}$ for SRG and CTRM, respectively), which remained constant from that moment on, despite those recorded in the other positions increased during delamination.

On the base of the results of bond testing with different anchorage lengths and on the strain profiles derived from strain gauges, an effective anchorage length can be identified. As regards SRG, it can be estimated to be slightly above 220 $\mathrm{mm}$, since on the one hand the strain gauge placed at $220 \mathrm{~mm}$ distance from the specimen edge recorded almost null values up to the activation of debonding (Fig. 12a), but on the other hand, a slight increase of the load was observed for bonding length longer than $220 \mathrm{~mm}$ (Fig. 10). Concerning CTRM, a slight increase in load is recorded when the anchorage length increases from $165 \mathrm{~mm}$ to $220 \mathrm{~mm}$ (Fig. 10 ); while the strain profiles show a change in the curvature with almost null strain at the gauges located $162 \mathrm{~mm}$ apart from the loaded edge (Fig. 12b). Therefore, the effective anchorage length can be assumed to be slightly higher than $165 \mathrm{~mm}$. As for BTRM, a small increase of the ultimate load was found for the three considered bonding lengths (Fig. 10); however, in the absence of strain profile, a reliable estimate of the effective anchorage length cannot be derived.

Clearly, the values of debonding load and anchorage length derived in the present study are only valid in case of pure shear while can't be considered reliable in case of bending (reinforcement of beams) or of curved surface of the substrate (reinforcement of arches and vaults), due to the presence of normal stresses on the substrate-reinforcement interface.

\section{CONCLUSIONS}

The present experimental study provides an overview on the mechanical behaviour of EB mortar-based composites conceived for application to masonry structures, based on the experiences gained from three laboratories on different reinforcement systems and substrates. The outcomes show that the tensile behaviour and the bond performance strongly depend on the mechanical properties of mortar matrix and textile, on the layout of the textile, and on the surface roughness of the substrate.

The stress-strain relationships show three different stages under tension, such as uncracked, crack-development and cracked. The contribution of the mortar matrix is prevalent in the first two stages, while in the cracked stage the stiffness and the ultimate tensile strength of the composite are close to those of the textiles alone. Both the ultimate tensile stress and the Young's modulus of BTRM are not strongly influenced by the number of textile layers embedded in the mortar. In CTRM the weak textile-to-matrix bond does not ensure full load distribution, which may induce premature rupture due to stress concentration. Differently from Carbon and Basalt, SRG displayed a slightly non-linear behavior before failure, which occurs at much higher stress values.

Testing methodologies are discussed in the perspective of developing a standardized procedure, to be potentially used in both the production process, as a material qualification step, and the design/building process, to assess the effectiveness of the installation. In tensile testing, an effective gripping means has to be devised to ensure uniform stress transfer and slip-free gripping of the 
coupon. Due to the differences among the strengthening systems, the clamping method may vary depending on the textile-to-matrix bond/interlocking properties. Additionally, a strain and displacement acquisition method is advised that avoids crack-induced erroneous readings.

Bond tests carried out on brick substrates for SRG and CTRM and on stone substrates for BTRM, showed that higher bond performances are achieved with mortar matrices of higher strength, with stiffer textiles (the stiffer is the textile the longer the transfer length), and with suitable substrate preparation techniques (e.g., sand-blasting) that increase the surface roughness. Three main failure modes were identified: debonding at substrate-matrix interface (failure mode a), debonding at the textile-matrix interface (b) and slipping of the fibre rovings from the matrix (c). Failure mode (a) generally occurred for short anchorage lengths with SRG reinforcements, while failure modes (b) and (c) were observed for long anchorage lengths of CTRM and BTRM, due to the worse interlocking between textile and matrix. Even if carbon and basalt reinforcements are made out of bidirectional meshes, in which transverse fibre rovings improve the matrix-totextile bond, sliding of the fibre roving was observed. This phenomenon needs to be deeply investigated and its structural effects possibly exploited in those applications that prioritize fracture toughness over strength. Conversely, sliding of the textile within the matrix could be prevented by improving the fibre-to-mortar chemical bond and interlocking.

Both single lap and double lap setups proved to be reliable: the former allows the direct load measurement, the latter guarantees pure shear stress development on the substrate-to-reinforcement interface, thanks to symmetry. The strain gauges applied over the bonded length proved to give accurate readings, provided that they are carefully applied to the textile during the specimen manufacturing.

Clearly, a much larger quantity of experimental results are needed before some more general conclusions can be drawn and results can be directly applied in design practice. The present study may however constitute a background for future research for the development of EB mortar-based systems for the strengthening of masonry.

\section{REFERENCES}

Ascione L, Feo L, Fraternali F (2005) Load carrying capacity of 2D FRP/strengthened masonry structures. Compos Part B-Eng 36(8):619-626

Babaeidarabad S, De Caso F, Nanni A (2013) Out-of-Plane behavior of URM walls strengthened with fabric-reinforced cementitious matrix composite. J Compos Constr

Balsamo A, Di Ludovico M, Prota A, Manfredi G (2011) Masonry walls strengthened with innovative composites. American Concr Inst, ACI Spec Publ 2(275):769-786

Borri A, Castori G, Corradi M (2011) Shear behavior of masonry panels strengthened by high strength steel cords. Constr Build Mater 25(2):494-503

Brameshuber W (2006) Textile reinforced concrete. State-of-the-art report of RILEM Technical Committee 201-TRC. Report 36, Bagneux, RILEM

Cancelli AN, Aiello MA, Casadei P (2007) Experimental investigation of bond properties of SRP/SRG - masonry systems. In: Fiber Reinforced Polymer Reinforcement for Concrete Structures - FRPRCS-8, Proc 8th Int Symp, Patras, Greece 
Carbone I, de Felice G (2008) Bond performance of fibre reinforced grout on brickwork specimens. In: Proc SAHC 2008 6th International Conference on Structural Analysis of Historic Constructions, Bath, UK

Carbone I, de Felice G (2009) Debonding of CTRM composite on masonry support. In: Proc Prohitec 09 Int Conf on Protection of Historical Buildings, Rome, Italy

Carozzi FG, Milani G Poggi C (2014) Mechanical properties and numerical modeling of Fabric Reinforced Cementitious Matrix (FRCM) systems for strengthening of masonry structures. Compos Struct 107:711-725

Ceroni F, de Felice G, Grande E, Malena M, Mazzotti C, Sacco E, Valluzzi MR (2014). Modeling of the FRP-masonry bond behavior. THIS ISSUE.

CNR (2012). CNR-DT 200 R1/2012. Guidelines for the Design and Construction of Externally Bonded FRP Systems for Strengthening Existing Structures. Italian Research Council, Italy.Colombo I G, Magri A, Zani G, Colombo M, di Prisco M (2013) Textile Reinforced Concrete: experimental investigation on design parameters. RILEM Mater Struct. Doi: 10.1617/s11527-013-0017-5

Contamine R., Si Larbi A. Hamelin P. (2011) Contribution to direct tensile testing of textile reinforced concrete (TRC) composites. Mater Sci Eng, 528, pp. 8589-8598

Corradi M, Borri A, Vignoli A (2002) Strengthening techniques tested on masonry structures struck by the Umbria-Marche earthquake of 1997-1998. Constr Build Mater 16(4):229-239

Cuypers H, Wastiels J (2006) A stochastic cracking theory for the introduction of matrix multiple cracking in textile reinforced concrete under tensile loading. In: Proc 1st International RILEM Symposium. RILEM Technical Committee 201-TRC. Aachen, Germany, pp 193-202

D'Ambrisi A, Feo L, Focacci F (2013) Experimental and analytical investigation on bond between Carbon-FRCM materials and masonry. Compos Part B-Eng 46:15-20

D'Antino T, Carloni C, Sneed LH, Pellegrino C (2014) Matrix-fiber bond behavior in PBO FRCM composites: A fracture mechanics approach. Engng Fract Mech 117:94-111

EN 1015-11 (2007) Methods of test mortar for masonry - Part 11: Determination of flexural and compressive strength of hardened mortar

EN 1926 (2006) Natural stone test methods. Determination of uniaxial compressive strengthEN 772-1 (2002) Methods of test for masonry units - Part 1: Determination of compressive strength

Faella C, Martinelli E, Paciello S, Nigro E (2008) Adhesion of Advanced Composites on Masonry: Experimental Study and Numerical Analysis. In: Proc CICE2008 Fourth Int Conf on FRP Composites in Civil Engineering, Zurich, $\mathrm{CH}$

Garmendia L, San-José JT, García D, Larrinaga P (2011) Rehabilitation of masonry arches with compatible advanced composite material. Constr Build Mater 25(12):4374-4385

Garmendia L, San-José JT, Larrinaga P, García D (2012) Textile Reinforced Mortar as strengthening material for masonry arches. Int $\mathrm{J}$ Architectural Heritage Doi:10.1080/15583058.2012.704480

Grande E, Imbimbo M, Sacco E (2011) Bond behaviour of CFRP laminates glued on clay bricks: Experimental and numerical study. Compos Part B-Eng 42(2):330-340

Grande E, Imbimbo M, Sacco E (2013) Modeling and numerical analysis of the bond behavior of masonry elements strengthened with SRP/SRG. Compos Part B-Eng 55:128-138

Hartig J, Jesse F, Schicktanz K, Häußler-Combe U (2012) Influence of experimental setups on the apparent uniaxial tensile load-bearing capacity of Textile Reinforced Concrete specimens. RILEM Mater Struct 45(3):433-446

Häußler-Combe U, Hartig J (2007) Bond and failure mechanisms of textile reinforced concrete (TRC) under uniaxial tensile loading. Cem Concr Compos 29(4):279-289.

Hegger J, Will N, Bruckermann O, Voss S (2006) Load-bearing behaviour and simulation of textile reinforced concrete. RILEM Mater Struct 39(8):765-776 
ICC (2013). AC434 Proposed acceptance criteria for masonry and concrete strengthening using fiber-reinforced cementitious matrix (FRCM) composite systems. ICCEvaluation Service, Whittier, CA

Malena M, de Felice G (2014) Externally bonded composites on a curved masonry substrate: experimental results and analytical formulation. Compos Struct 112:194206

Matana M, Nanni A, Dharani L, Silva P, Tunis G (2005) Bond performance of steel reinforced polymer and steel reinforced grout. In: Proc Int Symp on Bond Behaviour of FRP in Structures (BBFS), Hong Kong, China

Ohno S, Hannant DJ (1994) Modeling the stress-strain response of continuous fiber reinforced cement composites. ACI Mater J 91(3):306-312

Oliveira DV, Basilio I, Lourenço PB (2011) Experimental bond behavior of FRP sheets glued on brick masonry. ASCE J Compos Constr 15(1):32-41

Ortlepp R, Hampel U, Curbach M (2006) A new approach for evaluating bond capacity or TRC strengthening. Cem Concr Compos 28(7):589-597

Pacheco-Torgal F, Jalali S (2011) Cementitious building materials reinforced with vegetable fibres: A review. Constr Build Mater 25(2):575-581

Papanicolaou CG, Triantafillou TC, Karlos K, Papathanasiou M (2007) Textilereinforced mortar (TRM) versus FRP as strengthening material of URM walls: inplane cyclic loading. RILEM Mater Struct 40(10):1081-1097

Papanicolaou CG, Triantafillou TC, Papathanasiou M, Karlos K (2008) Textilereinforced mortar (TRM) versus FRP as strengthening material of URM walls: outof-plane cyclic loading. RILEM Mater Struct 41(1):143-157

Triantafillou TC, Fardis MN (1997) Strengthening of historic masonry structures with composite materials. RILEM Mater Struct 30:486-496

Valluzzi MR, Modena C, de Felice G (2014) Current practice and open issues in strengthening historical buildings with composites. THIS ISSUE.

Valluzzi MR, Oliveira DV, Caratelli A, Castori G, Corradi M, de Felice G, Garbin E, Garcia D, Garmendia L, Grande E, Ianniruberto U, Kwiecień A, Leone M, Lignola GP, Lourenço PB, Malena M, Micelli F, Panizza M, Papanicolaou CG, Prota A, Sacco E, Triantafillou TC, Viskovic A, Zając B, Zuccarino G (2012) Round Robin test for composite-to-brick shear bond characterization. RILEM Mater Struct 45(12):1761-1791

Valluzzi MR, Valdemarca M, Modena C (2001) Behavior of brick masonry vaults strengthened by FRP laminates. ASCE J Compos Constr (5)3:163-169 


\section{LIST OF FIGURE CAPTIONS}

Fig. 1 Setup used for tensile tests by UNIRM3 (a), UMINHO (b) and TECNALIA (c)

Fig. 2 Stress-strain curves of SRG (a), CTRM (b), and BTRM (c) specimens under uniaxial tension.

Fig. 3 Tensile tests on BTRM: development of the crack pattern in the middle third of the specimens on series TB2 with 2 layers (a) and TB3 with 3 layers (b)

Fig. 4 Single-lap (SL) setup for bond shear tests carried out at UMINHO (a) and TECNALIA (b)

Fig. 5 Double lap setup for shear bond tests: type 1 (DL1, a) and type 2 (DL2, b)

Fig. 6 Failure modes: debonding at substrate-matrix interface and peeling of the brick surface (a), debonding at textile-matrix interface (b) and slipping of the textile from the matrix (c)

Fig. 7 Failure modes in SRG specimens. Effect of anchorage length: debonding at the substrate-matrix interface in specimens with anchorage length of $55 \mathrm{~mm}$ (a) and at the textile-matrix interface in specimens with anchorage length of $220 \mathrm{~mm}$ (b) (all specimens received minimal surface preparation prior to SRG application). Effect of surface preparations: specimens with minimal preparation (c) and with sand-blasted surface (d)

Fig. 8 Failure modes in BTRM specimens: debonding at the substrate-matrix interface in specimens with anchorage length of $85 \mathrm{~mm}$ (a) and slipping of the fibre rovings from the matrix in specimens with anchorage length of $220 \mathrm{~mm}$ (b)

Fig. 9 Failure modes in CTRM specimens: slipping of the fibre rovings from the matrix in specimens with anchorage length $55 \mathrm{~mm}$ (a) and $110 \mathrm{~mm}$ (b) and combined failure with initial debonding of the matrix and subsequent slipping of the fibre rovings from the matrix in specimens with anchorage length $165 \mathrm{~mm}(\mathrm{c}, \mathrm{d})$

Fig. 10 Ultimate load per unit width vs. anchorage length

Fig. 11 Load-displacement curves for SRG (a) and CTRM (b) on brick substrates, and for BTRM (c) reinforcement on stone substrates

Fig. 12 Strain profiles for SRG (a) and CTRM (b) reinforcements

\section{LIST OF TABLE CAPTIONS}

Table 1 Compressive properties of substrates and matrices

Table 2 Textile tensile properties

Table 3 Overview of the direct tensile tests on strengthening systems

Table 4 Mean values of the results of tensile tests

Table 5 Results of bond tests 